\title{
IMPLEMENTASI UNDANG-UNDANG NOMOR. 28 TAHUN 2014 TENTANG HAK CIPTA TERHADAP PERLINDUNGAN KARYA CIPTA PROGRAM KOMPUTER (SOFTWARE) DI PERTOKOAN RIMO DENPASAR.
}

\author{
I Gede Ari Krisnanta Permana, Ratna Artha Windari, Dewa Gede Sudika Mangku \\ Jurusan IImu Hukum \\ Universitas Pendidikan Ganesha \\ Singaraja, Indonesia.
}

E-mail : \{krisnanta.permana,ratnawindari,dewamangku\}@undiksha.ac.id

\begin{abstract}
Abstrak
Penelitian ini bertujuan untuk mengetahui (1) Faktor Penyebab Terjadinya Pelanggaran Karya Cipta Program Komputer (Software) di Pertokoan Rimo Denpasar, (2) Akibat Hukum Terhadap Pelaku Pelanggaran Karya Cipta Program Komputer (Software) di Pertokoan Rimo Denpasar. Teknik penentuan sampel penelitian ini menggunakan snowball sampling. Subjek penelitian ini adalah Pelaku Usaha, Konsumen/Pengguna program komputer (software), Polresta Denpasar dan objek penelitian ini adalah program komputer (software) bajakan, serta lokasi penelitian di Pertokoan Rimo Denpasar. Jenis Penelitian ini dengan metode pendekatan yuridis empiris. Teknik pengumpulan data dalam penelitian ini adalah teknik studi dokumen, teknik wawancara (interview) dan teknik observasi. Data yang dikumpulkan dianalisis secara deskriptif kualitatif. Hasil penelitian menunjukkan, (1) Faktor yang melatarbelakangi terjadinya pelanggaran karya cipta dibidang program komputer (software) adalah faktor ekonomi dimana semakin tinggi tingkat kebutuhan konsumen akan suatu produk maka semakin banyak pula tingkat ketersediaan produk, selain itu pelanggaran program komputer (software) ini juga dipengaruhi oleh struktur hukum yang memiliki kewenangan dalam hal menangani pelanggaran terhadap hak cipta. (2) Akibat hukum terhadap pelaku pelanggaran karya cipta program komputer (software) dikaji berdasarkan pasal 113 ayat (3) UndangUndang Hak Cipta dimana pelaku pembajakan program komputer (software) dikenakan pidana 4 (empat) tahun penjara dan/atau pidana denda paling banyak Rp.1.000.000.000,00 (satu miliar rupiah) akan tetapi belum terlaksana dengan baik sehinga program komputer (software) bajakan masih sangat banyak diperjual belikan dan struktur hukum dalam hal ini POLRESTA Denpasar belum mampu untuk melaksanakan ketentuan tentang hak cipta dengan baik karena hak cipta terkait dengan program komputer (software) merupakan delik aduan yang mana harus ada aduan dari masayarakat yang merasa dirugikan.
\end{abstract}

Kata Kunci : Pertokoan Rimo Denpasar, Hak Cipta, Program Komputer (software) bajakan, Struktur Hukum. 


\begin{abstract}
This study aims to determine (1) The factors that make the violation of copyright of computer program (software) happen. (2)The law effect to the offenders of copyright of computer program (software) at Rimo Denpasar. The sampling technique of this research is snowball sampling. The subjects of this research are Business Executors, Software / users of computer program (software), Polresta Denpasar and the object of this research is the pirated of computer program (software), and research location of this research at Rimo Denpasar. The type of this research is empirical juridical approach. Data collection techniques that used in this research are document study techniques, interview techniques (interviews) and observation techniques. The data collected were analyzed by descriptive qualitative. The result of this research showed

(1) Factors behind the occurrence of copyright violation in the field of computer programs (software) is an economic factor where the higher level of consumer demand for a product, then the more the level of product. Besides, the violations of computer programs (software)is also affected by the law structure that the authority has in terms of handling violations of copyright. (2) The law consequences of computer software program (software) actors are reviewed based on Article 113 paragraph (3) Copyright Law where the perpetrators of piracy computer program (criminal software) 4 (four) years imprisonment and / or maximum fine of Rp. 1,000,000,000.00 (one billion rupiah, but that is not be able to execute properly so there are still so many pirated computer programas (software)and the law structure in this case POLRESTA Denpasar can not be able to implement the provisions on copyright properly because the copyright associated with the computer program (software) is a complaint which complaint there must be complaints from people who feel harmed.
\end{abstract}

Key Words: Rimo Denpasar Stores, Copyright, Pirated Computers Program (software), Law Structure

\section{PENDAHULUAN}

Dari tahun ke tahun pemanfaatan teknologi informasi dan komunikasi kian pesat digunakan, yang mana pemanfaatannya dapat diamati di masyarakat hingga saat ini. Salah satu contoh pemanfaatan teknologi informasi dan komunikasi ada pada beberapa produk elektronik yang telah beredar saat ini di masyarakat salah satunya adalah komputer. Komputer berasal dari bahasa latin computare yang mengandung arti menghitung. Komputer adalah suatu alat yang mampu melakukan tugas seperti menerima dan memproses input data sesuai dengan programnya serta menyimpan perintah-perintah dan hasil dari pengolahan, serta menyediakan output dalam bentuk suatu informasi (Jogiyanto H.M, 1989 : 3).

$$
\text { Pada umumnya bagi para }
$$

mahasiswa, komputer merupakan alat penunjang yang berperan penting dalam perkuliahan khususnya dalam hal mengerjakan tugas-tugas, mencari informasi yang ada di internet dan membuat kebutuhan lain seperti desain, edit vidio, edit foto. Mengingat pentingnya peran komputer dikalangan mahasiswa dapat diasumsikan bahwa hampir semua mahasiswa memiliki perangkat komputer, namun demikian sangat mungkin pula ada beberapa kalangan mahasiswa yang tidak memiliki perangkat komputer. Kemungkinan diatas justru menjadi peluang bisnis bagi para pelaku usaha yang mulai membuka usaha di bidang penyewaan komputer. Hal ini dapat diamati dilapangan secara langsung, seperti di seputaran lingkungan Universitas Pendidikan Ganesha yang mana mulai banyak bermunculan tempat- tempat penyewaan komputer sebagaimana dimaksud diatas. Untuk membuka usaha penyewaan komputer pelaku usaha tentu membutuhkan perangkat komputer, yang mana perangkat komputer dibeli dari pelaku usaha penjual perangkat komputer. Berdasarkan hasil obeservasi di 6 (enam) pelaku usaha yang menyewakan 
komputer di seputaran lingkungan Universitas Pendidikan Ganesha diketahui bahwa keseluruhan dari pelaku usaha tersebut membeli perangkat komputer di pertokoan Rimo Denpasar. Pertokoan Rimo Denpasar adalah sebuah pertokoan yang ada di kawasan Denpasar dengan keunggulan menjual segala bentuk barang elektronik yang berkaitan dengan komputer atau bisa disebut sebagai pusat dari penjualan komputer terlengkap di-Bali yang beralamat di Jalan Diponegoro 136 Denpasar-Bali. Adapun yang melatar belakangi dibelinya komputer tersebut di Pertokoan Rimo Denpasar adalah sebagai berikut :

1. Ada banyak pilihan merek;

2. Asecoris yang banyak;

3. Harga Software terjangkau;

4. Menyediakan Purna Jual;

5. Melayani pembayaran secara angsuran;

Beranjak dari informasi yang diberikan oleh pelaku usaha yang menyewakan komputer sebagaimana telah dipaparkan diatas, maka berdasarkan hasil observasi yang dilakukan di Pertokoan Rimo Denpasar, para pelaku usaha membenarkan alasan- alasan tersebut. Selain membenarkan alasan-alasan sebagaimana dimaksud diatas, diperoleh informasi tambahan bahwa ada dua jenis komputer yang dijual di Pertokoan Rimo Denpasar. Jenis yang pertama adalah Komputer Build-Up, yakni komputer yang keseluruhan perangkat kerasnya (hardware) dibuat dan dirakit oleh salah satu produsen pembuat komputer. Jenis yang kedua adalah Komputer Rakitan yakni komputer yang semua perangkat kerasnya (hardware) berasal dari berbagai merek dan dirakit oleh toko komputer yang menjual komputer rakitan tersebut.

Perangkat komputer yang terdiri dari beberapa gabungan komponen berupa hardware belum mampu dioperasionalkan tanpa adanya dukungan software. Software adalah program komputer yang berisi perintah-perintah atau intruksi untuk melaksanakan suatu proses pada hardware. Adapun beberapa software penting yang harus ada untuk dapat mengoperasionalkan

seperangkat

komputer adalah :

1. Operating system

2. Application software

Pada umumnya dikenal 2 (dua) jenis software yakni software original (asli) dan software bajakan. Software asli adalah software yang dipasang atau diinstal di dalam komputer dengan sebuah CD atau DVD tanpa menggunakan keygen, serial number, crack ataupun generator keygen. Software bajakan adalah software asli dengan kondisi yang sudah dirubah komponennya agar dapat dipakai atau digunakan tanpa melakukan sebuah transaksi pembayaran. Berdasarkan hasil observasi, adapun software yang dipasang pada komputer yang diperjual belikan di pertokoan Rimo Denpasar adalah beragam. Pada komputer Buil-Up dipasang software asli, alasannya adalah bahwa untuk menciptakan unsur keaslian dalam komputer yang dibuat selain itu mampu bertahan dengan waktu yang lama tanpa adanya gangguan seperti pemberitahuan memasukkan serial number dan software not responding (macet) dan lebih aman dari gangguan virus yang masuk kedalam sistem komputer. Sedangkan pada komputer rakitan cenderung dipasang software bajakan, dengan alasan utama bahwa software bajakan lebih murah bila dibandingan dengan software original (asli) hal ini diharapan mampu menekan biaya produksi perangkat komputer serendah mungkin sehingga tercapai prinsip ekonomi yakni mendapatkan barang dengan harga yang murah dengan kualitas yang memadai.

Berbicara tentang software dari sudut pandang studi keilmuan dibidang hukum khususnya hukum Hak Kekayaan Intelektual (selanjutnya disingkat HKI) maka software (program komputer) diberikan perlindungan hukum berdasarkan ketentuan yang ada didalam Undang-Undang Nomor. 28 tahun 2014 tentang Hak Cipta (selanjutnya disingkat UU Hak Cipta). Berdasarkan ketentuan Pasal. 40 ayat (1) UU Hak Cipta, ditentukan bahwa program komputer merupakan ciptaan dibidang ilmu pengetahuan yang dilindungi. Selanjutnya 
berdasarkan ketentuan Pasal. 40 ayat (3) UU Hak Cipta dinyatakan bahwa, "Pelindungan sebagaimana dimaksud pada ayat (1) dan ayat (2), termasuk pelindungan terhadap ciptaan yang tidak atau belum dilakukan pengumuman tetapi sudah diwujudkan dalam bentuk nyata yang memungkinkan penggandaan ciptaan tersebut". Ketentuan tersebut memberi arti bahwa program komputer mendapatkan perlindungan hak cipta setelah diwujudkan dalam bentuk nyata meski belum dilakukan pengumuman.

Beranjak dari adanya peredaran software bajakan sebagaimana telah diuraikan diawal yang tentunya dimulai dari adanya proses pembajakan yang dilakukan oleh pihak-pihak tertentu, maka hal tersebut mengindikasikan bahwa masih banyak terjadi pelanggaran hak cipta dibidang program komputer yang terjadi di Indonesia. Hal tersebut diperkuat dari data laporan Bussines Alliance (BSA) dan International Data Corporation (IDC) dalam Annual Global Software Privacy Study 2015, dimana Indonesia masuk ke dalam Negara terbersar ke-10 di dunia dalam tingkat pembajakan software yang mencapai $85 \%$ (delapan puluh lima persen). Pelanggaran tersebut tentu akan sangat merugikan pihak pencipta mengingat bahwa hak cipta adalah hak eksklusif yang menadung dua macam hak sebagaimana ditentukan dalam ketentuan Pasal. 4 UU Hak Cipta, yakni Hak Moral dan Hak Ekonomi. (http://migasnet04david078.blogspos.com/ 2015/05/indonesia-pembajak-softwareurutan10.html).Kondisi seperti ini sangat berpengaruh terhadap perkembangan software yang ada di Indonesia karena pembajakan dapat mematikan kreasi karya cipta dibidang industri software.

Beranjak dari kondisi yang demikian, maka peneliti berkeinginan untuk mengkaji lebih lanjut mengenai "IMPLEMENTASI

UNDANG-UNDANG NOMOR. 28 TAHUN 2014 TENTANG HAL CIPTA TERHADAP PERLINDUNGAN KARYA CIPTA PROGRAM KOMPUTER (SOFTWARE) DI PERTOKOAN RIMO DENPASAR".

\section{METODE PENELITIAN}

Berdasarkan fokus masalah penelitian yang di fokuskan di atas, maka penelitian ini secara metodologis menggunakan pendekatan yuridis empiris (Zainuddin, 2013:30). Dengan rasionalitas untuk mengkaji kesenjangan dari kententuan Undang-Undang No.28 tahun 2014 Tentang Hak Cipta terkait mengenai perlindungan software dengan software bajakan yang beredar di Pertokoan Rimo Denpasar. Oleh karena itu penelitian ini akan dimulai dari obervasi awal untuk menentukan urgensi masalah, melakukan wawancara, studi dokumen, memfokuskan data dan mendeskripsikan data sesuai dengan alur penelitian kualitatif. Deskriptif analisis yakni penyajian dengan menggambarkan aspek-aspek tertentu yang berkaitan dengan masalah dan kemudian di analisa untuk mendapatkan kebenaran serta berusaha memahami kebenaran tersebut dengan memperhatikan fenomena hukum yang ada di masyarakat (Zainuddin, 2013:6).

Apabila keseluruhan data yang diperoleh baik dari data primer maupun data sekunder sudah terkumpul, data-data tersebut dianalisis melalui proses pengolah, pemisahan, pengelompokan, serta memadukan sejumlah data yang telah dikumpulkan. Data-data yang ada dihubungkan satu sama lainnya, dilakukan interprestasi untuk memahami makna data dalam situasi sosial, kemudian dilakukan suatu penafsiran. Setelah dilakukan analisa secara kualitatif, selanjutnya data disajikan secara deskriptif kualitatif dan sistematis guna mendapatkan kesimpulan sebagai akhir dari penelitian ini.

\section{HASIL DAN PEMBAHASAN}

HKI merupakan hak atas suatu benda atau hak kebendaan maka hak tersebut tidak terlepas dari harta kekayaan. Salah satu kajian HKI adalah terkait mengenai Hak Cipta dimana hak cipta disini mengandung 2 (dua) macam hak yakni hak moral dan hak ekonomi. Hak Moral adalah hak yang melekat pada diri pencipta sedangkan hak ekonomi adalah hak untuk mengumumkan (right to publish atau right to perform) dan hak untuk memperbanyak (right to copy atau mechanical right) ciptaan. Hak yang paling 
sering dilanggar dalam hak cipta adalah hak ekonomi dimana sering kali terjadi penggunaan karya berhak cipta yang melanggar hak eksklusif pemegang hak cipta. Sesuai dengan Undang-Undang No. 28 tahun 2014 pelanggaran hak cipta dikenal sebagai pembajakan.Pembajakan adalah Penggandaan ciptaan dan/atau produk Hak Terkait secara tidak sah dan pendistribusian barang hasil penggandaan dimaksud secara luas untuk memperoleh keuntungan ekonomi. Sesuai dengan Pasal 34 Undang-Undang No. 19 tahun 2016 pembaharuan Undang-Undang Nomor 11 tahun 2008 tentang Informasi dan Transaksi Elektronik, pembajak adalah setiap orang yang sengaja dan tanpa hak atau melawan hukum memproduksi, menjual, mengadakan untuk digunakan, mengimpor, mendistribusikan, menyediakan atau memiliki. Dalam penelitian ini yang menjadi pokok utama pembajakan adalah software komputer yang dijual di Pertokoan Rimo Denpasar. Pertokoan Rimo Denpasar adalah sebuah pertokoan yang menjual segala bentuk barang elektronik yang berkaitan dengan komputer atau bisa disebut sebagai penjual komputer dan accecoris komputer terlengkap dibali, dari keunggulan penjualan elektronik yang dijual disana maka tak heran adapun oknum yang menjual barang baik perangkat lunak ataupun perangkat keras yang berhubungan dengan komputer dengan tidak menghiraukan keorisinalitasan atau keaslian dari barang tersebut salah satunya adalah software bajakan. Sebenarnya pembajakan software yang beredar dipertokoan Rimo Denpasar sudah jelas melanggar ketentuan yang berlaku yaitu Undang-Undang No. 28 tahun 2014 tentang Hak Cipta atau bisa disebut tidak benar, dari ketidak benaran tersebut timbul sebuah masalah yang terjadi dimana masalah tersebut adalah kensenjangan antara das sollen dengan das sein atau bisa disebut dengan kesenjangan antara peraturan perundang- undngan yang mengatur mengenai perlindungan hak cipta program komputer (software) dengan kejadian yang ada dilapangan.
Dari penelitian dilapangan yang sudah dilakukan tepatnya dipertokoan Rimo Denpasar mengai software bajakan adapun data yang diperoleh adalah permasalahan mengnai pelanggaran karya cipta yang ber-hak cipta seperti program komputer (software) sangat banyak hal ini dapat dilihat dari hasil penelitian dilapangan dimana dari 200 (dua ratus) penjual komputer yang ada dipertokoan Rimo Denpasar, 60\% (enam puluh persen) diantaranya atau 80 (delapan puluh) penjual komputer menyatakan bahwa mereka menjual software copyan atau bajakan dengan menginstalkan ke komputer yang dibeli oleh konsumen maupun software yang dibeli langsung oleh konsumen. Tanggapan masyarakat terkait software bajakan yang beredar sangat beragam ada pihak-pihak yang merasa diuntungkan dan ada pihak yang merasa dirugikan. Pihak pertama yang mendapat keuntungan dari produk bajakan adalah para pembajak. Secara ekonomis pelaku pembajakan software mendapatkan keuntungan yang paling banyak dan besar, karena tanpa bersusah payah dapat menjual karya orang lain. Dengan adanya pembajakan software, produsen atau perusahaan pembuat software secara otomatis akan mengalami kerugian karena secara langsung keuntungan dari produk yang dibuat dalam hal ini adalah software menurun, penyebab menurunnya keuntungan perusahaan pembuat software adalah karena penjualan produk software yang kalah bersaing dipasaran dengan software bajakan yang beredar dimasayarakat, dan ketika keuntungan perusahaan dari produk yang dibuat menurun maka penghasilan perushaan pembuat software akan ikut melemah dan berakibat pada bangkrutnya perushaan tersebut (Gautama, 1995 : 11).

Sementara jika dilihat dari sisi konsumen terkait software bajakan beragam, ada yang merasa dirugikan dan ada yang merasa diuntungkan. Konsumen yang dirugikan adalah konsumen yang membeli dengan harga software asli (original) tetapi pada kenyataanya mendapatkan software bajakan. Sedangkan konsumen yang diuntungkan 
adalah konsumen yang memang secara sadar menghendaki atau membeli software bajakan. Meskipun demikian banyak sekali kerugian yang diakibatkan ketika menggunakan software bajakan, Berikut merupakan beberapa kerugian menggunakan software bajakan: potensi terkena virus dan sejenisnya lebih besar, tidak support update terbaru, mudah mengalami heng atau crash, mudah kena blacklist, dikenali oleh antivirus sebagai virus, tidak ada garansi, banyak fitur nonaktif.

Secara umum berdasarkan penelitian yang didapatkan di Pertokoan Rimo Denpasar, penyebab terjadinya tindak pelanggaran karya cipta program komputer (software) adalah sebagai berikut :

1. Faktor ekonomi, pada dasarnya memang keinginan untuk mencari keuntungan financial secara cepat dan menggabaikan kepentingan para pencipta dan pemegang hak cipta. Begitu juga dengan harga yang terjangkau bagi masyarakat dimana harga sebuah software bajakan dapat dibeli dengan harga berkisar anataraRp.50.000.00,- (lima puluh ribu rupiah) sampai dengan Rp.100.000.00,- (seratus ribu rupiah).

2. Faktor substansi Hukum, pada dasarnya ketentuan yang berlaku yaitu Undang-Undang No. 28 tahun 2014 tentang hak cipta masih menggunakan delik aduan, yang mana delik aduan yang dimagsud adalah diadukan oleh pencipta atau pihak yang merasa dirugikan akan tetapi hal tersebut sebenarnya sangat merugikan pencipta karena umumnya pembajakan software yang dilakukan adalah pembajakan software umum seperti : Microsoft, Adobe, Antivirus dan lain sebgainya, yang memang penciptanya bukan dari Indonesia sehingga mereka tidak mengetahui ada pembajakan yang dilakukan atas software yang diciptakan.

3. Faktor Struktur Hukum, pada dasarnya struktur hukum tidak akan bisa bergerak tanpa adanya substansi hukum yang mana substansi hukum yang dimagsud masih menggunakan delik aduan sehingga pihak dari struktur hukum dalam hal ini kepolisian harus menunggu pengaduan pihak pencipta yang merasa dirugikan agar bisa menjalankan aturan hukum yang berlaku selain itu tidak adanya ketentuan yang dibuat oleh pihak kepolisian dalam hal ini POLRESTA Denpasar untuk melaksanakan sidak berkaitan dengan pelanggaran hak cipta khususnya program komputer (software) bajakan.

4. Faktor Budaya Hukum Masyarakat, terkait budaya hukum masyarakat khususnya pelaku usaha dan konsumen tekait perlindungan terhadap hak cipta software ditengah maraknya pelanggaran yang terjadi di Pertokoan Rimo Denpasar maka berdasarkan hasil penelitian dapat diketahui bahwa budaya hukum masyarakat dalam hal ini masih lemah. Hal tersebut dikarenakan hal - hal sebagai berikut :

1. Pemahaman konsumen tentang keberadaan Undang-Undang No. 28 tahun 2014 tentang hak cipta yang memberikan perlindungan terhadap karya cipta software.

Ada konsumen yang sama sekali tidak mengetahui adanya aturan mengenai perlindungan hak cipta khususnya perlindungan terhadap software.

- Ada konsumen yang sekedar mengetahui adanya aturan mengenai perlindungan hak cipta akan tetapi tetap menggunakan software bajakan dengan alasan mahalnya software asli, dan mudahnya mendapatkan software bajakan tanpa menunggu berhari-hari.

2. Pemahaman pelaku usaha tentang keberadaan UndangUndang No. 28 tahun 2014 
tentang hak cipta yang memberikan perlindungan terhadap karya cipta software.

Ada pelaku usaha yang sama sekali tidak

mengetahui adanya aturan mengenai perlindungan hak cipta khususnya perlindungan terhadap software. Disamping itu menurut pelaku usaha permintaan akan software bajakan ini sangat tinggi bila dibandingkan dengan software asli.

- Ada pelaku usaha yang sekedar mengetahui adanya aturan mengenai perlindungan hak cipta akan tetapi tetap menjual software bajakan dengan alasan menurut pelaku usaha permintaan akan software bajakan ini sangat tinggi bila dibandingkan dengan software alsi.

Jadi secara umum faktor yang timbul akibat kesadaran masyarakat terhadap barang bajakan yang illegal yang masih sangat tinggi dan kesadaran masyarakat terhadap barang asli yang tidak illegal yang masih sangat lemah. Masyarakat hanya mementingkan harga yang murah dan dapat dinikmati kegunaan dari software bajakan tersebut. Masyarakat kurang mendapatkan informasi bahwa barang bajakan tersebut tidak boleh beredar, dan bila mengedarkan akan terkena sanksi hukum yang sesuai dengan peraturan yang berlaku.

Penggunaan CD-RW dan DVD-RW pada PC (komputer) hingga alat yang saat ini popular yaitu hardisk dan flashdisk membuat kasus pembajakan software semakin marak dilakukan dimasyarakat. Kemampuan alat ini untuk menciptakan software lebih banyak dimanfataatkan oleh pengguna komputer untuk menggandakan software dengan mudah tanpa mengurangi kualitas produknya. Bahkan produk hasil penggandaanya akan berfungsi sama seperti software yang asli. Selain mengakibatkan kerugian pada perusahaan komputer yang menciptakan software, pembajakan juga mengakibatkan pelanggaran hak cipta. Memang tidak dapat dipungkiri bahwa semakin meluasnya penggunaan teknologi komputer untuk kantor maupun pribadi memungkinkan setiap individu di seluruh dunia untuk menggandakan software tanpa diketahui oleh pemilik hak cipta sehingga pembajakan software sulit untuk diawasi dan ditindak. Namun sejauh ini berbagai upaya tengah dilakukan pemerintah untuk melindungi property intellectual hasil inovasi mereka dari pembajakan.

Pemerintah mengeluarkan aturan hukum berkaitan dengan Undang-Undang No. 28 tahun 2014 tentang Hak Cipta mengenai tata cara perlindungan program komputer (software), berbagai bentuk pembajakan serta sanksi bagi pelaku pembajakan program komputer (software) serta aturan aturan lain yang mengatur dan berkaitan dengan perlindungan program komputer (software). Dalam ketentuan umum pasal 1 angka 9

Undang-Undang No. 28 tahun 2014 tentang Hak Cipta, "Program Komputer adalah seperangkat instruksi yang diekspresikan dalam bentuk bahasa, kode, skema, atau dalam bentuk apapun yang ditujukan agar komputer bekerja melakukan fungsi tertentu atau untuk mencapai hasil tertentu".

Undang-Undang No. 28 tahun 2014 tentang Hak Cipta menentukan bahwa Program Komputer (software) mendapatkan perlindungan hukum yang sama dengan karya cipta lainnya. Hal ini dapat dilihat pada pasal 40 ayat (1) huruf s, menyatakan bahwa program komputer merupakan salah satu ciptaan yang dilindungi. Jadi perlindungan hukum terhadap program komputer (software) juga lahir secara otomatis ketika program tersebut diciptakan. Terhadap perlindungan karya cipta atas perlindungan program komputer (software) perlu diketengahkan bahwa perlindungan karya atas program komputer (software) bukan atas judul program komputer (software) tersebut. 
Judul atau bentuk penamaan-penamaan lainnya bukan merupakan perhatian dari system hukum Hak Cipta, melainkan lapangan hukum Merek. Hak cipta tidak memberikan Pemegang Hak Cipta atas program komputer (software) hak monopoli terhadap bagaimana cara program komputer (software) tersebut bekerja, tetapi hukum hak cipta memberikan hak bagi pemegang hak cipta atas program komputer untuk melarang pihak lain yang meniru, menjiplak ekspresi dari instruksi atas program komputer (software) yang dapat diaplikasikan dalam perangkat komputer tersebut (Margono, 2003 : 69). Pemegang hak atas program komputer (software) mempunyai beberapa hak ekslusif diantaranya :

1. Hak untuk memperbanyak program komputer (software) dalam sebuah bentuk material (hak ini termasuk menggandakan program komputer (software) tersebut dalam harddisk atau flashdisk dari sebuah komputer, menulis atau mencatatkan kode sumber dari program komputer (software)).

2. Hak untuk mengumumkan program komputer (software) (hal ini berarti membuat program komputer (software) telah diumumkan kepada publik di indonesia).

3. Membuat adaptasi dari program (hal ini berarti membuat sebuah versi lain dari program tersebut, seperti membuat versi Bahasa lain, kode atau notasi dari program komputer (software) tersebut).

Jangka waktu perlindungan program komputer (software) didalam UndangUndang Hak Cipta pasal 59 ayat (1) berlaku selama 50 (lima puluh) tahun sejak pertama kali diumumkan. Pelanggaran terhadap hak cipta program komputer (software) dapat dikenakan tuntutan secara pidana ataupun perdata. Didalam pasal 9 ayat (1) huruf b Undang- Undang hak Cipta menyebutkan bahwa pemegang hak cipta yang memiliki hak ekonomi untuk melakukan penggandaan ciptaan dalam segala bentuknya termasuk program komputer (software) dan ketika itu dilanggar maka Dalam Undang- Undang No. 28 tahun 2014 tentang Hak
Cipta telah mengatur mengenai sanksi pidana bagi pelanggar hak cipta program komputer (software) yang dijelaskan pada pasal 113 ayat (3) yang menjelaskan bahwa "Setiap Orang yang dengan tanpa hak dan/atau tanpa izin Pencipta atau pemegang Hak Cipta melakukan pelanggaran hak ekonomi Pencipta sebagaimana dimaksud dalam Pasal 9 ayat (1) huruf $a$, huruf $b$, huruf e, dan/atau huruf $g$ untuk Penggunaan Secara Komersial dipidana dengan pidana penjara paling lama 4 (empat) tahun dan/atau pidana denda paling banyak Rp1.000.000.000,00 (satu miliar rupiah)".

Disamping itu ketentuan pidana lain yang mengatur terkait perlindungan program komputer (software) adalah Undang-Undang Nomor 19 tahun 2016 pembaharuan atas Undang-Undang Nomor 11 tahun 2008 tentang Informasi dan Transaksi Elektronik pasal 30 ayat (3) "Setiap orang yang snegaja dan tanpa hak atau melawan hukum mengakses computer dan atau system elektronik dengan cara apapun dengan melanggar, menerobos, melampaui, atau menjebol system pengaman (cracking, hacking, illegal access). Ancaman pidana pasal 46 ayat 3 setiap orang yang memenuhi unsur sebagaimana dimaksud dalam pasal 30 ayat 3 dipidana dengan pidana penjara paling lama 8 (delapan) dan atau denda paling banyak Rp.800.000.000,00 (delapan ratus juta rupiah), pasal 32 " (1) Setiap Orang dengan sengaja dan tanpa hak atau melawan hukum dengan cara apapun mengubah, menambah, mengurangi, melakukan transmisi, merusak, menghilangkan, memindahkan, menyembunyikan suatu Informasi Elektronik dan/atau Dokumen Elektronik milik Orang lain atau milik publik. (2) Setiap Orang dengan sengaja dan tanpa hak atau melawan hukum dengan cara apa pun memindahkan atau mentransfer Informasi Elektronik dan/atau Dokumen Elektronik kepada Sistem Elektronik Orang lain yang tidak berhak. (3) Terhadap perbuatan sebagaimana dimaksud pada ayat (1) yang mengakibatkan terbukanya suatu Informasi Elektronik dan/atau Dokumen Elektronik yang bersifat rahasia menjadi 
dapat diakses oleh publik dengan keutuhan data yang tidak sebagaimana mestinya. Dipidana dengan ketentuan pasal 48 (1) Setiap Orang yang memenuhi unsur sebagaimana dimaksud dalam Pasal 32 ayat (1) dipidana dengan pidana penjara paling lama 8 (delapan) tahun dan/atau denda paling banyak Rp2.000.000.000,00 (dua miliar rupiah).

(2) Setiap Orang yang memenuhi unsur sebagaimana dimaksud dalam Pasal 32 ayat (2) dipidana dengan pidana penjara paling lama 9 (sembilan) tahun dan/atau denda paling banyak Rp3.000.000.000,00 (tiga miliar rupiah). (3) Setiap Orang yang memenuhi unsur sebagaimana dimaksud dalam Pasal 32 ayat (3) dipidana dengan pidana penjara paling lama 10 (sepuluh) tahun dan/atau denda paling banyak Rp5.000.000.000,00 (lima miliar rupiah)." Pasal 33 "Setiap orang yang sengaja dan tanpa hak atau melawan hukum melakukan tindakan apapun yang berakibat terganggu system elektronik dan atau mengakibatkan system elektronik menjadi tidak bekerja sebagaimana mestinya, dipidana dengan pidana penjara paling lama 10 (sepuluh) tahun dan/atau denda paling banyak Rp10.000.000.000,00 (sepuluh miliar rupiah).", Pasal 34 "Setiap orang yang sengaja dan tanpa hak atau melawan hukum memproduksi, menjual, mengadakan untuk digunakan, mengimpor, mendistribusikan, menyediakan atau memiliki, dipidana dengan pidana penjara paling lama 10 (sepuluh) tahun dan/atau denda paling banyak Rp10.000.000.000,00 (sepuluh miliar rupiah)", Pasal 35 "Setiap orang dengan sengaja dan tanpa hak atau melawan hukum melakukan manipulasi, penciptaan, perubahan, penghilangan, pengrusakan informasi elektronik dan atau dokumen elektronik dengan tujuan agar informasi elektronik dan atau dokumen elektronik tersebut seolah-olah data yang otentik (Phising=penipuan situs) dipidana dengan pidana penjara paling lama 12 (dua belas) tahun dan/atau denda paling banyak Rp12.000.000.000,00 (dua belas miliar rupiah)."

Dari aturan yang sudah dipaparkan dapat dianalisis bahwa pembajakan sebenarnya tidak disarankan dan kegiatan pembajakan melanggar ketentuan hak cipta yang sudah diatur dalam ketentuan perundang-undangan hal tersebut juga terdapat sanksi hukum baik kurungan maupun denda secara tegas dan tertulis, akan tetapi ketentuan dan sanksi tersebut tidak dilakasanakan sesuai dengan aturan oleh para pelaku usaha, konsumen ataupun penegak hukum. Dari hasil penelitian yang dilaukan dipertokoan Rimo Denpasar dan konsumen yang pernah membeli barang di Pertokoan Rimo Denpasar hal tersebut terbukti. Dari hasil wawancara yang dilakukan dilapangan untuk pemesanan sebuah komputer akan langsung diberikan program (software) yang dikehendaki oleh pemesan komputer tersebut. Software yang diinstall tersebut bukanlah software yang asli, melainkan software bajakan yang diinstall melalui perantara hardware / perangkat keras (harddisk).

Selain itu dari hasil penelitian kepada pelaku usaha yang memiliki toko komputer dipertokoan Rimo Denpasar 80 (delapan puluh) pelaku usaha mejual software bajakan dan mengakui bahwa software bajakan lebih banyak yang meminati dari pada software asli yang dijual. Selain itu harga software bajakan yang dijual terjangkau dan sangat murah sesuai dengan ekonomi masyarakat, sebagai contoh software Windows 10 Home yang asli harganya bisa mencapai US\$199 atau setara dengan Rp. 2.900.000.00,- (dua juta sembilan ratus rupiah) sedangkan software bajakan dapat dibeli dengan harga Rp.100.000.00,- (seratur ribu rupiah). Jadi apabila pembeli tidak meminta software asli maka pembeli akan diberikan software bajakan dengan harga yang murah dan kualitas yang hampir sama dibandingkan dengan software aslinya. Jika ditinjau dari penegakan hukum perlindungan hak cipta dibidang program komputer (software) sudah sangat jelas terdapat dalam pasal 40 Undang-Undang No. 28 tahun 2014 tentang hak cipta bahwa salah satu ciptaan yang dilindungi adalah program komputer, hal tersebut diperkuat oleh pihak kepolisian dalam hal ini POLRESTA Denpasar yang menyatakan bahwa aturan 
baku terkait dengan perlindungan hak cipta khususnya program komputer sudah sangat jelas terdapat di dalam UndangUndang No. 28 tahun 2014 sehingga acuan utama ketika terjadi pelanggaran mengenai Hak Cipta khususnya program komputer adalah Undang-undang tersebut, semestinya dari aturan hukum sudah sangat jelas bahwa program komputer (software) dilindungi. Ketika terjadi sebuah pelanggaran terkait dengan hak cipta dibidang program komputer dalam hal ini software bajakan yang dijual dipertokoan Rimo Denpasar pihak kepolisian seharusnya sesekali mengadakan sweeping atau sidak ataupun menyita software bajakan tersebut, akan tetapi berbeda dengan keterangan pelaku usaha yang menjual produk di pertokoan Rimo Denpasar sweeping petugas kepolisian terkait dengan perlindungan software bajakan di Pertokoan Rimo Denpasar sangat jarang terjadi dan bahkan tidak pernah dilakukan tindakan. Pada umumnya software bajakan dan keberadaan pembajak tidak tersentuh hukum, banyak para pedagang produk atau software bajakan dengan leluasa menjual produk tersebut secara terbuka. Lemahnya pengawasan dari aparat penegak hukum (dalam hal ini kepolisian) dan peraturan perundang- undangan mengenai hak cipta yang masih menggunakan delik aduan menyebabkan perlindungan hak cipta dibidang perlindungan program komputer (software) dan pembajakan software yang ada dimasyarakat khususnya dipertokoan Rimo Denpasar marak dilakukan.

\section{SIMPULAN DAN SARAN}

Berdasarkan dari hasil penelitian dan pembahasan pada bab-bab sebelumnya maka dapat ditarik beberapa kesimpulan, sebagai berikut : 1. Adapun faktor-faktor yang
melatarbelakangi terjadinya pelanggaran tersebut yakni bahwa sangat dipengaruhi oleh faktor ekonomi masyarakat, faktor substansi hukum yang masih menggunakan delik aduan, faktor struktur hukum yang kurang makasimal dalam menjalankan substansi karena adanya delik aduan dan faktor kesadaran masyarakat yang sangat kurang mengenai perlindungan program komputer (software).

2. Secara substansi perlindungan terhadap hak cipta di bidang program komputer (software) telah diatur dalam Undang-Undang Nomor 28 Tahun 2014 tentang Hak Cipta (selanjutnya disingkat Undang-Undang Hak Cipta) sebagaimana dengan tegas dirumuskan dalam ketentuan Pasal 40 ayat 1 huruf S dan sanksinya pada pasal 113 ayat (3) Undang-Undang Hak Cipta. Namun demikian dalam pengimplementasiannya ketentuan tersebut seakan tidak diperhatikan dan justru diabaikan oleh pelaku usaha yang memperjual belikan program komputer (software) komputer bajakan. Sejalan dengan hal tersebut adapun ketentuan Undang-Undang No 28 tahun 2014 tentang hak cipta belum sepenuhnya dapat diterapkan oleh struktur hukum (POLRESTA Denpasar) yang dilatar belakangi oleh karena pelanggaran hak cipta adalah merupakan delik aduan yang mana artinya bahwa pelanggaran tersebut hanya bisa ditindak apabila adanya laporan dari masyarakat dan/atau pihak yang merasa dirugikan.

Saran-saran yang dapat diberikan untuk permasalahan diatas adalah sebagai berikut:

1. Saran kepada pemerintah untuk mengkaji ulang terkait mengenai aturan UU Hak Cipta yang masih menggunakan delik aduan dengan mennganti menggunakan delik laporan atapun delik lain agar nantinya tidak terjadi atau meminimalisir pelanggaran hak cipta khususnya mengenai program komputer (software) bajakan.

2. Mengingat bahwa tingkat pelanggaran terhadap hak cipta yang terjadi di pertokoan rimo denpasar sangat tinggi, maka dalam hal ini sudah seharusnya menjadi tanggung jawab semua komponen masyarakat untuk turut serta melakukan pengawasan baik secara langsung maupun tidak langsung terhadap eksistensi dari 
peredaran program komputer (software) bajakan, dalam artian bahwa ada kerjasama antara masyarakat dan aparat penegak hukum terkait upaya perlindungan hukum terhadap hak cipta, adapun kerja sama yang dimaksud dalam hal ini adalah dalam bentuk kesediaan masyarakat untuk melaporkan dan/atau mengadukan setiap tindakan yang mengarah pada pelanggaran hak cipta.

3. Bagi sekala Internasional BSA (Business Software Alliance) untuk lebih sering memberikan pemahaman baik secara tertulis di social media maupun website yang mudah diakses oleh masyarakat dan presentasi di masyarakat untuk mempromosikan basic software open source sebagai langkah untuk mengurangi pembajakan khususnya di Indonesia.

\section{DAFTAR PUSTAKA}

Buku :

Ali, Zainuddin, 2013, Metode Penelitian Hukum, edisi-1, cetakan ke-4, Sinar Grafika, Jakarta.

Friedman,M,Lawrence, 1969, The Legal System: Social Scince Perspektif, Russel Soge Foundation, New York.

Gautama, Sudargo, 1989, Perkembangan Arbitrase Dagang Indonesia, Eresco, Bandung.

Jogiyanto, H.M, 1989, Pengenalan Komputer, Edisi ke-1, Cetakan ke-1, Andi offset, Yogyakarta.

Margono, Suyud, 2003, Hukum dan Perlindungan Hak Cipta, CV. Novinda Pustaka Mandiri, Jakarta.

Saidin, OK, 2015, Aspek Hukum Hak Kekayaan Intelektual (Intellectual Property Rights), PT Raja Grafindo Persada, Jakarta.

\section{Peraturan Perundang-undangan :}

Indonesian Civil Code Burgelijk Wetbook Voor Indonesia (Kitab UndangUndang Hukum Perdata), Terjemahan Ali Afandi, 1984, Gajah Mada, Yogyakarta.

Republik Indonesia, Undang-Undang Nomor 28 Tahun 2014 Tentang Hak Cipta, Lembaran Negara Nomor 5599.

Republik Indonesia, Undang-Undang Nomor 19 Tahun 2016 Tentang Perubahan Undang- Undang Nomor 11 tahun 2008 tentang Informasi dan Transaksi Elektronik,

Tmabhan Lembaran Negara Nomor. 4843.

Republik Indonesia, Undang-Undang Nomor 30 Tahun 1999 Tentang Arbitrase dan Alternative Penyelesaian Sengketa, Lembaran Negara Nomor 138.

\section{Internet :}

Susanto, David, 2009, "Indonesia Pembajak Software Urutan 10 Dunia", 28 September 2017, http://migasnet04david078.blo gspos.com/2015/05/indonesiapembajak-softwareurutan10.html.

www.wipo.int/sme/en/documents/guides/.2 $\underline{006}$. 